University of Wollongong

Research Online

Faculty of Social Sciences - Papers (Archive) Faculty of Arts, Social Sciences \& Humanities

2016

Introduction to "Construing Change: Special Issue from the 20th

International Congress on Personal Construct Psychology"

Peter Caputi

University of Wollongong, pcaputi@uow.edu.au

Follow this and additional works at: https://ro.uow.edu.au/sspapers

Part of the Education Commons, and the Social and Behavioral Sciences Commons

Research Online is the open access institutional repository for the University of Wollongong. For further information contact the UOW Library: research-pubs@uow.edu.au 


\title{
Introduction to "Construing Change: Special Issue from the 20th International Congress on Personal Construct Psychology"
}

\author{
Abstract \\ The 20th International Congress on Personal Construct Psychology was held in Sydney, Australia, in July \\ 2013. The theme of the congress centered on change, whether personal, societal, or organizational. \\ Thirty-four high-quality papers from national and international delegates were presented at the congress \\ over two days.

\section{Keywords} \\ issue, 20th, international, congress, personal, construct, psychology, introduction, construing, change, \\ special

\section{Disciplines} \\ Education | Social and Behavioral Sciences

\section{Publication Details} \\ Caputi, P. (2016). Introduction to "Construing Change: Special Issue from the 20th International Congress \\ on Personal Construct Psychology". Journal of Constructivist Psychology, 29 (4), 339.
}




\section{Introduction to "Construing Change: Special Issue from the 20th International Congress on Personal Construct Psychology"}

The 20th International Congress on Personal Construct Psychology was held in Sydney, Australia, in July 2013. The theme of the congress centered on change, whether personal, societal, or organizational. Thirty-four high-quality papers from national and international delegates were presented at the congress over two days.

This special issue contains five papers that reflect the quality and diversity of presentations at the congress. The first in the series, "To Live Is to Know, to Know Is to Change: Change in Personal Construct Psychology and Psychological Constructivism," is by Gabriele Chiari. This important theoretical treatise tackles questions such as, "Is psychology actually concerned with human change?" and, "Is personal construct psychology concerned with understanding human change?"

The second explores the personal constructs of amputee survivors of the Sierra Leone civil war. David Winter's paper, "Reconstructing Life as a One-Foot Man: Reflections on the Role of Football," explores how players from the Sierra Leone Single-Leg Amputee Football Club construe their experiences of forgiveness and recovery.

The third paper turns to repertory grid analysis. Repertory grid methodology pervades the personal construct psychology literature. Hierarchical cluster analysis is a commonly used statistical technique for analyzing repertory grid data. In their paper, "A New Development to Aid Interpretation of Hierarchical Cluster Analysis of Repertory Grid Data," Mark Heckmann and Richard Bell explore the use of bootstrapping to assist in how we interpret cluster analytic solutions.

The fourth paper, Aida Keane's "Narratives of Treatment Outcome," details an interview study conducted in Ireland with a group of clinicians. It attempts to understand how clinicians understand or judge their success or failure with clients who self-harm.

The final paper in the series is by Elena Bordin. "Adolescents in 'Transition': The Sexual Risk of Self-Channelization," presents a personal construct psychology account of risk taking among adolescents. This paper was awarded the Tom Ravenette prize for best student paper.

I trust you will enjoy reading these fine papers that captured the essence of the 20th International Congress. 